\title{
Journey of SDSSU towards Internationalization
}

\author{
Rudy F. Daling
}

\author{
College of Teacher Education (CTE), Surigao del Sur State University-San Miguel Campus, Philippines
}

\begin{abstract}
This paper examined the profile of SDSSU as it takes its journey towards internationalization. It used case study in which documentary analysis of a unit was applied. The profile of the university has potential conformities of high performance, from instruction to extension functions that are essentials for global marketing and competitiveness. Hence, it needs a number of employees, specifically in terms offaculty, as it is seen that the population of students is expecting to be increased due to the free tuition, and availability of grants and scholarship programs. It shows also high performance in terms of program accredited, board programs, and extension services. As to faculty, few meet the educational qualifications but it is evident that majority of them are aiming a highest educational qualifications. Lastly, majority of their level of trainings, conferences, and seminars they attended are in local level.

Keywords-Journey, Internationalization, Profile.
\end{abstract}

\section{INTRODUCTION}

Internationalization of higher institutions deliberates sustainability for improving quality, relevance, and competitiveness (Egron-Polak and Hudson, 2014). The significance of internationalization focuses to the developments of globalization. This study was undertaken to investigate on profile ensuring that Surigaodel Sur States University (SDSSU) meets international standards in carrying out its four-fold functions.

The significance of internationalization has been cited by different studies; Green (2012), Green (2013), Gacel-Ávila (2012),Altbach and Knight (2011), Xuan (2015), and Hénard, et.al. (2012).The success of internationalization in measuring both institutional performance and student learning outcomes (Green, 2012) plays a vital role in the institutional context that institutional performance and student learning perspective are related to prepare them as global citizens in achieving global learning (Green ,2013). It develop innovative approaches that improve relevance and function which a key strategy (Gacel-Ávila, 2012). Hence, it is the motives for growth in international higher education and the landscape of programs and institutions (Altbach\& Knight, 2011)that effectiveness of leaders influence from the organizational culture of internationalization (Xuan, 2015) can do to promote, to support, and to manage internationalization more effectively (Hénard, et.al., 2012).These facts claim that SDSSU needs to examine its readiness for internationalization.

The quest for internationalization of education has been a primordial concern among higher education institutions (Rosaroso et.al, 2015). The aforementioned studies contributed a common understanding that HEIs must embrace internationalization. Recently, the Surigaodel Sur State Univesity (SDSSU) submitted International Standardization of Organization (ISO) 9001:2015 certification and it was awarded last February 22, 2019. Hence,the conversion of Surigao del Sur State University (SDSSU) through RA 9998 from Surigao del Sur Polytechnic State College (SSPSC), which was approved on February 22, 2010, made it known as one of the prestigious institutions of the Philippines. According to UniRank (2019), formerly 4icu.org,among more than 200 colleges and universities of the Philippines, it is among the top 200 most popular Schools in the Philippines this 2019. In addition, the passing of its Multidisciplinary Research Journal in the criteria for journal Asian Citation Indexing on 2018 gives a wider avenue in disseminating research outputs published in journal.These facts imply that it is necessary to examine the profile of SDSSU to assess its readiness towards internationalization.

The readiness of SDSSU for internationalization is an inevitable challenge as part of globalizing institution. Thus, the results of this study could be the basis for future researchers to create and to improve a proposed intervention that could help SDSSU ready for internationalization as a foundation towards quality clienteles' services satisfaction and continual improvement (ISO 9001:2015).

\section{RESULTS AND DISCUSSIONS}

The succeeding figures and tables present the profile of the University. 


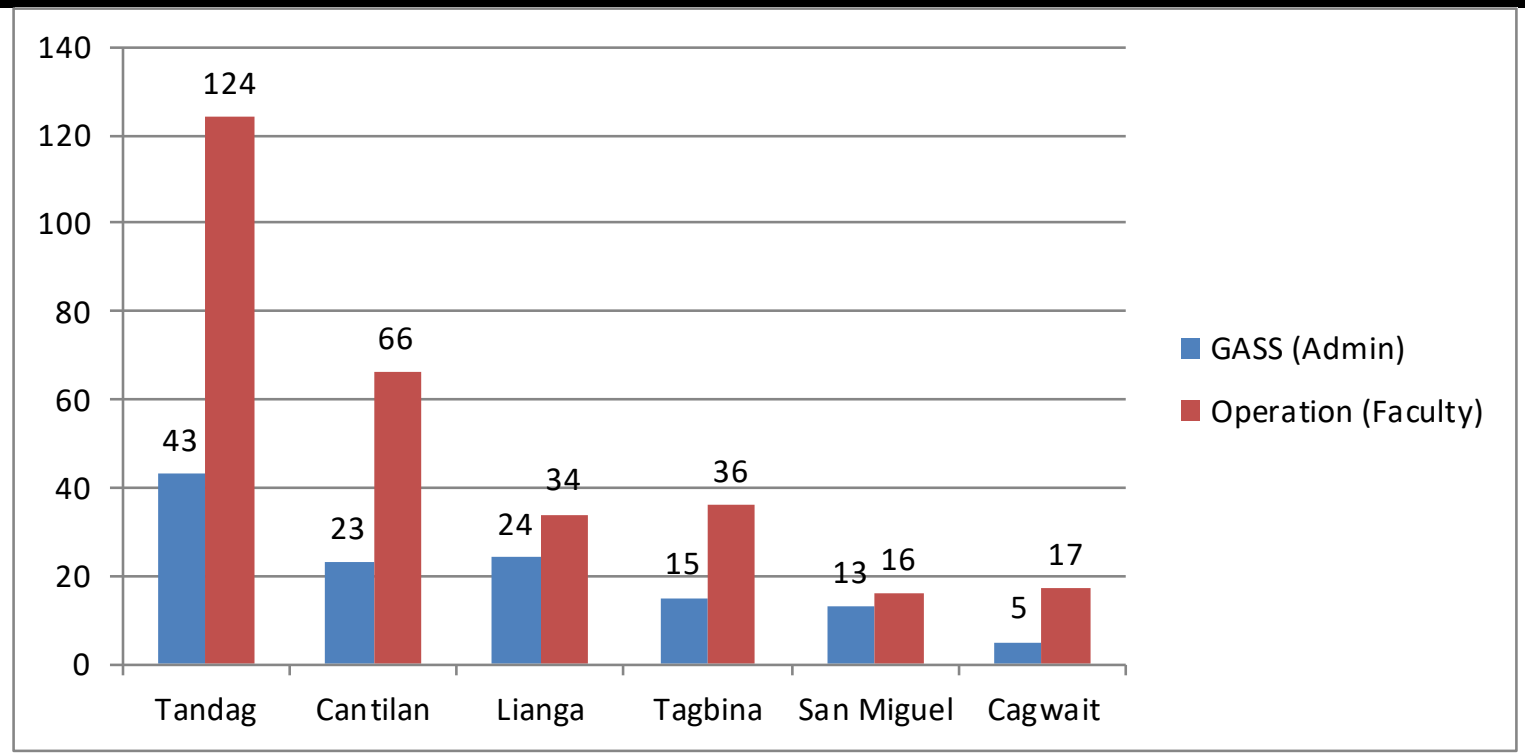

Fig.1: Summary of Employees as of November 2018

Figure 1 presents the bar graph of the summary of employees of SDSSU as of November 2018. Based on the figure 3 , the most number of personnel is concentrated in Tandag Campus showing an overall percentage of 124 or $42.43 \%$ of faculty and 43 or $34.96 \%$ administration employees, while Cagwait Campus having 17 or $5.80 \%$ of faculty and 5 or $4.07 \%$ administration employees. This is also a normal turnout because of the seat of governance of the SDSSU system is in Tandag City. Applicants also flock in the main campus because the student population which is around 4,000-5,000 per semester also needs a bigger number of faculty to handle them. SDSSU as an academic institution has a system of recruiting its personnel through its Personnel Selection Board (PSB) who does the interview before they will be recommended to the Board of Regents (BOR) for appropriate action. They peruse the applicant based on academic preparations and the overall preparations including character and attitude towards work. The selection committee comprised of the University's Vice Presidents, Campus Directors, BOR Secretary, HRMOS, and the Deans. According to Engetou (2017), the flexibility and productivity of the institution will determine its organizational performance. The equipment of an organization include capital, man, machine, and any other human resources. Further, he said that an organization which recruits enough personnel and has good management members can improve the overall work performance of the institution.

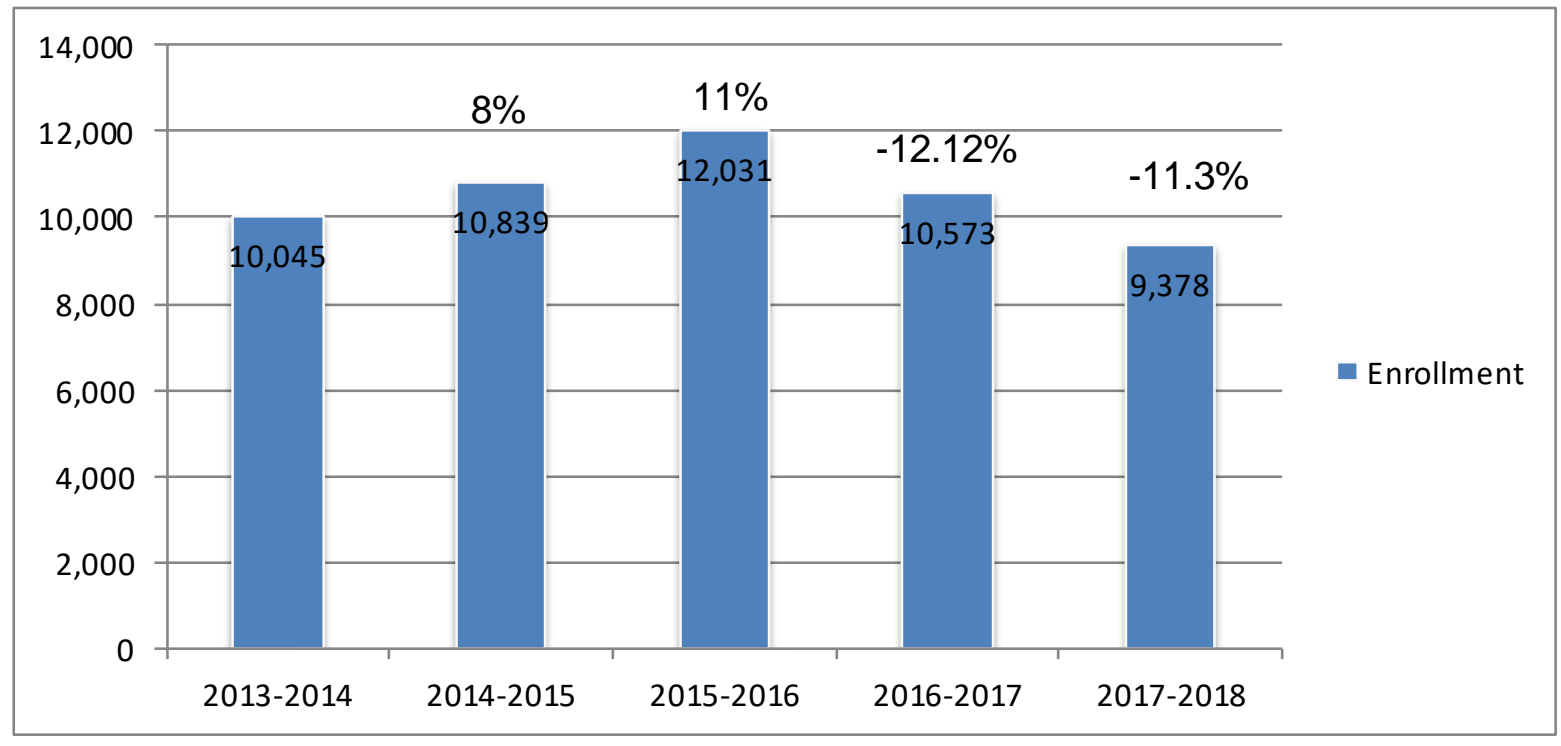

Fig.2: Enrollment Rate in the last 5 years 
SDSSU has a vibrant student population every semester. It caters students coming from the various municipalities of the Region. Figure 2 shows a bar graph of the enrollment rate of SDSSU in the last 5 years. It reveals that the highest enrollment rate is on 2015-2016 with an enrollment of 12,031 or $11 \%$. In the succeeding years, there is a fluctuation, but it rises back on AY 20172018. The fluctuation can be attributed to the fact that these enrollees contribute to their parent's livelihood to sustain the needs of the family. Many of the students belong to disadvantaged families and even with the free tuition fees, they still need to cater the needs on their food and lodging and their expenses for their school requirements. These among others become a reason why some of the students tend to stop pursuing their education.

Another reason could be the grueling demands of tertiary education that challenges them academically and psychologically causing them to drop from school. However, the free tuition fee scheme of the present
Government has also helped these students access higher education. According to Fisher and Scott (2011), tertiary education will benefit from its students once they become its alumni because they can transform the economy of the country using the skills they have acquired from their learning institution.

With the enactment of R.A.No. 10931 in promoting universal access to quality tertiary education by providing free tuition and school fees in SUCs, and the availability of scholarships and grants, opening of new curricular offerings, and the inclusion Bislig Campus in the SDSSU system, enrollment is expected to escalate in the coming years. In preparation for the burgeoning enrollment in the forthcoming years, the University through its current administration has prepared the infrastructure and its human resource to cater to the possible increase in enrollment.SDSSU makes good use of the Government's financial support to bring quality education to the people of the province and the Region.

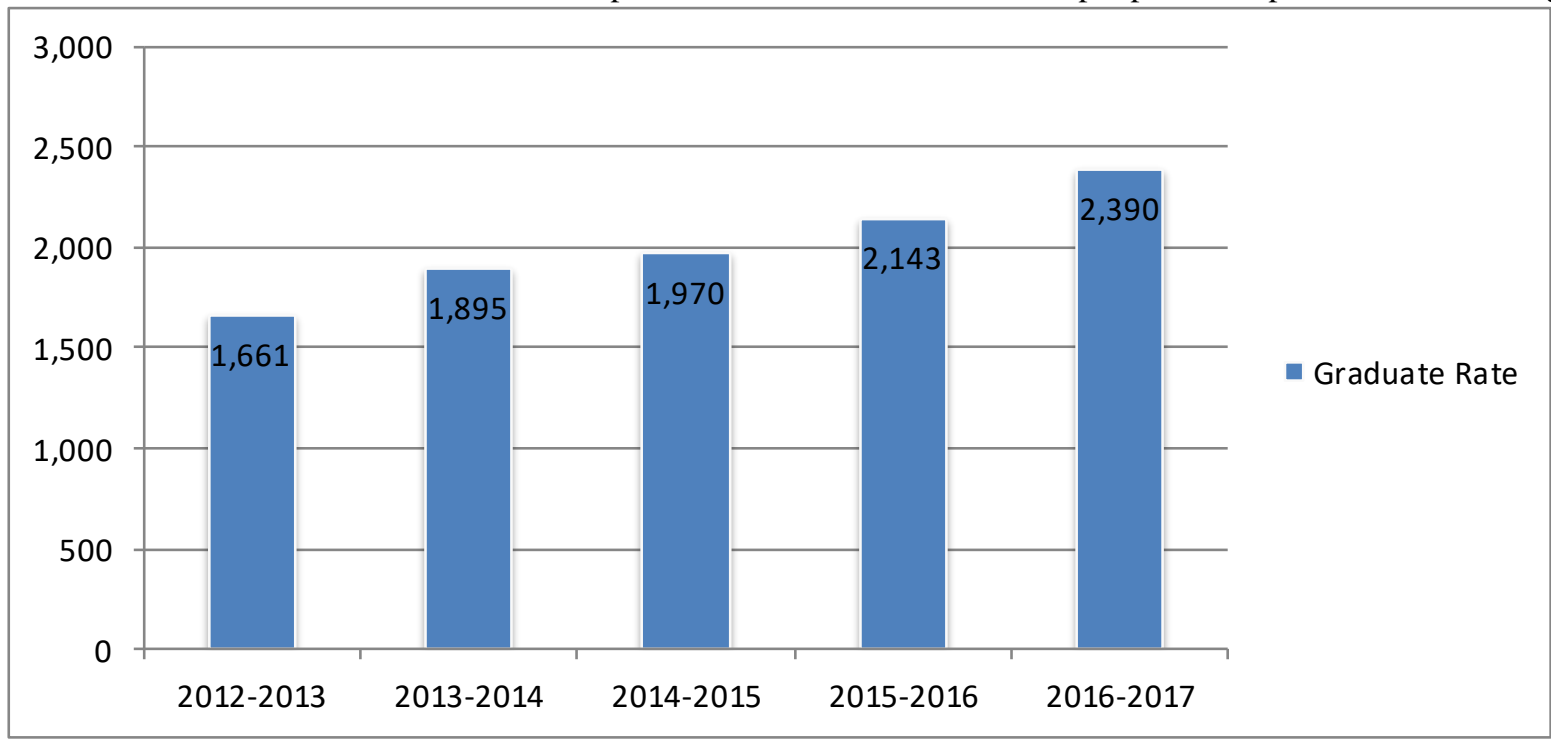

Fig.3: Graduate Rate in the last 5 years

Figure 3 presents a bar graph of graduate rate of SDSSU in the last five years. As it shows the academic year 2016-2017 has the highest rate of 2,390 graduate rate, while academic year 2012-2013 has the lowest rate of 1,661 graduate rate. This implies that there is constant increase of graduate rate of SDSSU. Hence, when there is a constant increase of graduate rate, there is a sustainable development of human resource. This finding conforms to the post of un.org (no date) that obtaining a quality education is the foundation to creating sustainable development. In addition, higher education represents a critical factor in innovation and human capital development and plays a central role in the success and sustainability of the knowledge economy (Dill and Van Vught, 2010).Thus, skills and human capital will become the backbone of economic prosperity and social wellbeing in the 21st century (OECD, 2012).

Table.1: Summary of the Program Accreditation

\begin{tabular}{|l|c|c|c|c|c|c|c|c|}
\hline \multirow{2}{*}{$\begin{array}{l}\text { SDSSU } \\
\text { Campuses }\end{array}$} & $\begin{array}{c}\text { Total No. } \\
\text { Of } \\
\text { Programs }\end{array}$ & \multicolumn{2}{|c|}{$\begin{array}{c}\text { No. of Accredited } \\
\text { Program by Level }\end{array}$} & I & TOTAL & $\begin{array}{c}\text { \% of } \\
\text { Accredited } \\
\text { Program }\end{array}$ & $\begin{array}{c}\text { No. of Non } \\
\text { Accredited } \\
\text { Program }\end{array}$ & $\begin{array}{c}\text { \% of Non } \\
\text { Accredited } \\
\text { Program }\end{array}$ \\
\cline { 3 - 8 } Tandag & 31 & 5 & 10 & 11 & 26 & $83.90 \%$ & 5 & $16.1 \%$ \\
\hline
\end{tabular}




\begin{tabular}{|l|c|c|c|c|c|c|c|c|}
\hline Cantilan & 13 & 1 & 3 & 8 & 12 & $92.30 \%$ & 1 & $7.7 \%$ \\
\hline Lianga & 9 & 2 & 7 & 0 & 9 & $100 \%$ & 0 & $0 \%$ \\
\hline Tagbina & 7 & 0 & 6 & 0 & 6 & $86.71 \%$ & 1 & $14.28 \%$ \\
\hline San Miguel & 4 & 3 & 0 & 0 & 3 & $75 \%$ & 1 & $25 \%$ \\
\hline Cagwait & 2 & 1 & 1 & 0 & 2 & $100 \%$ & 0 & $0 \%$ \\
\hline Total & $\mathbf{6 6}$ & $\mathbf{1 1}$ & $\mathbf{2 7}$ & $\mathbf{1 9}$ & $\mathbf{5 8}$ & & $\mathbf{8}$ & \\
\hline
\end{tabular}

Table 1 presents the summary of the program accreditation of SDSSU. As it shows, there are 58 accredited programs out of 66 programs offered by the SDSSU system, 27 programs are in Level II accredited while 11 are still in Level I. Across the table 3, both Lianga campus and Cagwait campus have the highest percent of accredited programs for it shows $100 \%$ of accredited program. This implies that the top management operates an ideal academe institutions consonance to the quality education standards that conforms to clienteles' satisfaction. This finding is conform to the statement of (Xuan, 2015) that internationalization motives for growth in higher education and the landscape of programs and institutions that effectiveness of leaders influence from the organizational culture of internationalization can do to promote, to support, and to manage internationalization more effectively.
Program accreditation is an important mechanism for quality assurance. Hence, SDSSU has also submitted its programs to this quality assurance activity involving its human resource and all other resources to ensure that the University has put in place all the aspects of its operations for quality service. From the table, it can be deduced that Tandag Campus has the most number of accredited programs ranging from Level I - III status. Understandably, the campuses with least number of program accreditation are those with small population in terms of students and manpower. Tandag also being the main campus strives to access quality assurance evaluations because it comprises four colleges to include: College of Business and Management, College of Teacher Education, College of Engineering Computer Studies and Technology, College of Arts and Sciences.

Table.2: Performance of Board Programs in Licensure Examination in 2017

\begin{tabular}{|c|c|c|c|c|c|c|c|c|c|c|c|c|c|c|c|c|c|c|c|}
\hline \multirow{2}{*}{ Boeerd Program } & \multicolumn{5}{|c|}{ Finstion } & \multirow{2}{*}{$\begin{array}{l}\text { Rate of } \\
\text { Accosel } \\
\text { lathment }\end{array}$} & \multicolumn{5}{|c|}{ Repeatars } & \multirow{2}{*}{$\begin{array}{c}\text { Rate of } \\
\text { Accompliah } \\
\text { ment }\end{array}$} & \multicolumn{5}{|c|}{ Overal Performance } & \multirow{2}{*}{$\begin{array}{l}\text { Rute of } \\
\text { Accoompl } \\
\text { lathment }\end{array}$} & \multirow[b]{2}{*}{ Rewaress } \\
\hline & Pased & Falled & Tots & SOSSU $\mathrm{K}$ & Mational's & & Pasued & Falled & Total & sossu \% & Mational $\$$ & & Pasud & Falled & Total & $\underset{x}{505 S U}$ & National $\mathbf{5}$ & & \\
\hline $\begin{array}{l}\text { IET } \\
\text { Eementary }\end{array}$ & 61 & 85 & 146 & $41.8 \%$ & $45.0 \%$ & $93 \%$ & 16 & 178 & 194 & $8.3 \%$ & $6.18 \%$ & $133.5 \%$ & $\pi$ & 263 & 340 & $22.65 \%$ & $19.94 \%$ & $114 \%$ & $\begin{array}{c}\text { Overall } \\
\text { performance } \\
\text { is above the } \\
\text { NPP }\end{array}$ \\
\hline $\begin{array}{c}\text { LET } \\
\text { Secondary }\end{array}$ & 210 & 159 & 369 & $56.9 \%$ & $723 \%$ & $79 \%$ & 76 & 394 & 470 & $162 \%$ & $21.80 \%$ & $74.2 \%$ & 286 & 553 & 839 & $34.09 \%$ & $39.88 \%$ & $85 \%$ & $\begin{array}{c}\text { Overall } \\
\text { performance } \\
\text { is below the } \\
\text { NPP }\end{array}$ \\
\hline $\begin{array}{c}\text { Civil } \\
\text { Engineering }\end{array}$ & 15 & 7 & 7 & $68.2 \%$ & $63.8 \%$ & $107 \%$ & 2 & 0 & 2 & $100 \%$ & $3208 \%$ & $311.7 \%$ & 17 & 7 & 24 & $70.83 \%$ & $38.57 \%$ & $184 \%$ & $\begin{array}{l}\text { Overal } \\
\text { performance } \\
\text { is above the } \\
\text { NPP }\end{array}$ \\
\hline Agriculture & 5 & 5 & 5 & $50.0 \%$ & $39.8 \%$ & $126 \%$ & 3 & 6 & 9 & $33.3 \%$ & $26.91 \%$ & $123.9 \%$ & 8 & 11 & 19 & $42.11 \%$ & $36.38 \%$ & $116 \%$ & $\begin{array}{c}\text { Overall } \\
\text { performance } \\
\text { is above the } \\
\text { NPP }\end{array}$ \\
\hline Fisheries & 5 & 19 & 19 & $20.8 \%$ & $39.9 \%$ & $52 \%$ & 3 & 20 & 23 & $13.0 \%$ & $21.26 \%$ & $61.4 \%$ & 8 & 39 & 47 & $17.02 \%$ & $31.75 \%$ & $54 \%$ & $\begin{array}{l}\text { Overall } \\
\text { pertormance } \\
\text { is below the } \\
\text { NPP }\end{array}$ \\
\hline Forestry & 1 & 2 & 2 & $33.3 \%$ & $71.0 \%$ & $47 \%$ & 2 & 3 & 5 & $40 \%$ & $25.72 \%$ & $155.5 \%$ & 3 & 5 & 8 & $37.50 \%$ & $42.22 \%$ & $89 \%$ & $\begin{array}{l}\text { Overall } \\
\text { performance } \\
\text { is below the } \\
\text { NPP }\end{array}$ \\
\hline Midwifery & 17 & 13 & 13 & $56.7 \%$ & $67.4 \%$ & $84 \%$ & 9 & 11 & 20 & $45 \%$ & $25.76 \%$ & $174.7 \%$ & 26 & 24 & 50 & $52 \%$ & $45.43 \%$ & $114 \%$ & $\begin{array}{c}\text { Overall } \\
\text { performance } \\
\text { is above the } \\
\text { NPP }\end{array}$ \\
\hline TOTAL & 314 & 290 & 604 & $51.99 \%$ & $53.57 \%$ & $97.0 \%$ & 111 & 612 & 723 & $15.4 \%$ & 1261 & $121.8 \%$ & 425 & 902 & 1327 & $32.03 \%$ & $31.51 \%$ & $101.6 \%$ & $\begin{array}{c}\text { Overall } \\
\text { performance } \\
\text { is above the } \\
\text { NPP }\end{array}$ \\
\hline
\end{tabular}

Table 2 shows the performance of board programs licensure examination in 2017 of SDSSU. It indicates the overall performance which is indicated from the performance of first takers and repeaters examinees. To 
sum up,it indicates that $32.03 \%$ is the overall performance of SDSSU which is above from the national passing percentage of $31.51 \%$. Hence, the rate of accomplishment of SDSSU is $101.6 \%$ that has a description of above the National Passing Percentage (NPP).

Furthermore, among the 7 board programs offered by SDSSU, Civil Engineering board program is the highest overall performance. As it shows, $70.83 \%$ is the overall performance percentage which is above from $38.57 \%$ of the NPP. Hence, civil engineering program takes pride in its PRC Licensure examination last November 2013 Board Exam, as it makes SDSSU ranked $7^{\text {th }}$ among school in the Philippines. This implies that SDSSU aspires to be an effective service provider, it adheres to quality standards and delivery of quality services to its clienteles and stakeholders. It contends with present day imperatives and realities as heightening global competitiveness (ISO 9001:2015).

According to Dotong \& Laguador (2015) that Quality Assurance mechanisms either locally or internationally recognized that utilized and adopted by the HEIs must reflect on the quality of their graduates which is one way of measuring the performance of an institution. They added that strengthening the degree program through QS World University Ranking by Subject must be the focus of the marketing strategy of the HEIs rather than promoting the institution as a whole. They concluded that international recognition of the program by subject could somehow uplift the credibility of the institution in the world market.

Table 3 presents the headcount of faculty with regular plantilla items by educational qualifications of SDSSU.

Table.3: Headcount of Faculty with Regular Plantilla Items by Educational Qualifications

\begin{tabular}{|l|c|c|c|c|c|c|c|}
\hline $\begin{array}{l}\text { Educational } \\
\text { Qualifications }\end{array}$ & $\begin{array}{l}\text { SDSSU- } \\
\text { Tandag }\end{array}$ & $\begin{array}{c}\text { SDSSU- } \\
\text { Cantilan }\end{array}$ & $\begin{array}{c}\text { SDSSU- } \\
\text { Lianga }\end{array}$ & $\begin{array}{c}\text { SDSSU- } \\
\text { Tagbina }\end{array}$ & $\begin{array}{c}\text { SDSSU- } \\
\text { San } \\
\text { Miguel }\end{array}$ & $\begin{array}{c}\text { SDSSU- } \\
\text { Cagwait }\end{array}$ & TOTAL \\
\hline $\begin{array}{l}\text { 1.PhD/EdD degree } \\
\text { holder }\end{array}$ & 31 & 16 & 3 & 4 & 1 & 2 & 57 \\
\hline $\begin{array}{l}\text { 2.Pursuing or w/ units } \\
\text { in doctorate program }\end{array}$ & 25 & 15 & 8 & 6 & 8 & 3 & 65 \\
\hline 3.Masters degree holder & 39 & 27 & 14 & 15 & 4 & 4 & 103 \\
\hline $\begin{array}{l}\text { 4.Pursuing or w/ units } \\
\text { in masters program }\end{array}$ & 31 & 10 & 10 & 12 & 3 & 8 & 74 \\
\hline TOTAL & 126 & 68 & 35 & 36 & 16 & 17 & 299 \\
\hline
\end{tabular}

As the campus with biggest student population, SDSSU Tandag serves as the highest workforce with 126faculty, while SDSSU San Miguel with 16 faculties is the lowest numbered faculty which is close to SDSSU Cagwait which is 17 out of 299 regular faculty. As shows in table 5, a total of 299 faculties who delivers the major services of SDSSU in terms instruction, research, and extension. Among of these faculties, Masters' degree holders are the most numbered educational qualification as it gives a total 103 faculties while 74 of them are still pursuing or with units in masters program. This implies that all programs or academe services delivered are manned by qualified educators. Hence, students are given quality higher services in education.
One of the requirements of QMS is the people which emphasize that the organization shall determine and provide the persons necessary for effective implementation of its quality management system and for the operation and control of its process. This statement is supported also in the study of Flores, et.al. (2012), as cited by Compe (2018), that academic preparation is very vital in any field of work. It is the source of all the knowledge that an individual need as he performs his/her daily tasks.

Figure 4 presents the summary of distribution of trainings, conferences, and seminars attended by the faculty. 


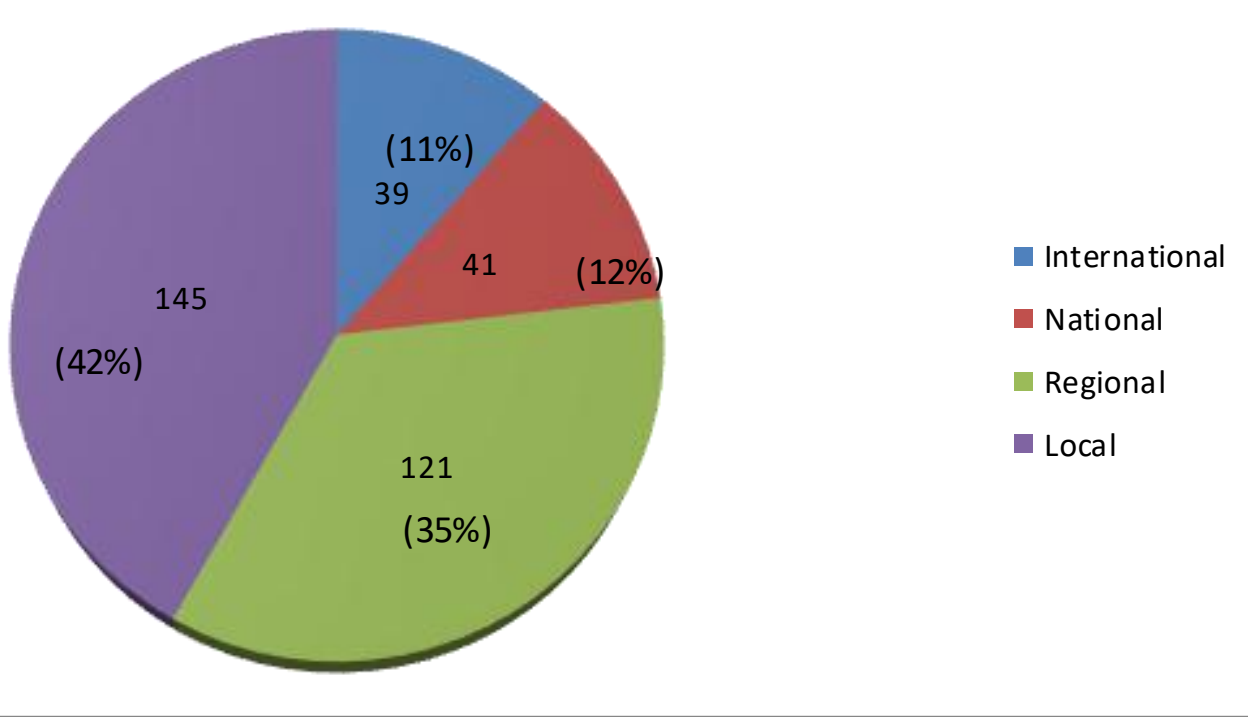

Fig.4: Summary of Distribution of Trainings, Conferences, and Seminars

As shows in figure 4,145 or $42 \%$ are trainings, conferences, and seminars most attended by faculty in local level, followed by 121 or $35 \%$ in the regional level, while 39 or $11 \%$ are in international level is the lowest distribution. This implies that there is continuous improvement in the professional development of the faculty. Faculty is self-motivated to learn more in his/her side of professional awareness.

The clause 7.2 (competence) of QMS requirements highlights that the organization shall determine the necessary competence of person ( $s$ ) doing work under its control that affects the performance and effectiveness of the quality management system; and ensure that these persons are competent on the basis of appropriate education, training, or experience. This statement is conforms to the statement of Llopsis (2014) that "No matter how much potential an employee has, it can remain dormant if not managed rightly and properly nourished with the right ingredients. A great leader will never allow an employee's potential to go unnoticed or to lose its momentum. Realizing potential to its fullest often requires breaking through barriers and creating new paradigms". It emphasizes that it is always encourage that as a good leader, he/she should not just see how his/her people jobs well but motivate him/her in discovering new standards that could increase productivity, sustainability and opportunities to the organization.

Table 4 presents the summary of performance of extension services indicators and targets 2017

Table.4: Summary of Performance of Extension Services Indicators and Targets 2017

\begin{tabular}{|l|c|c|c|}
\hline MFOs and Performance Indicators & $\begin{array}{c}\text { Institutional } \\
\text { Target }\end{array}$ & $\begin{array}{c}\text { Institutional } \\
\text { Accomplishment }\end{array}$ & $\begin{array}{c}\text { Accomplishment } \\
\text { Rate }\end{array}$ \\
\hline $\begin{array}{l}\text { 1.Number of persons trained weighted length of } \\
\text { training }\end{array}$ & 12,000 & $12,990.25$ & $108 \%$ \\
\hline $\begin{array}{l}\text { 2.Percentage of clients who rate the advisory } \\
\text { services as good or better }\end{array}$ & $95 \%$ & $98.33 \%$ & $103.5 \%$ \\
\hline $\begin{array}{l}\text { 3.Percentage of persons who received training or } \\
\text { advisory services who rated timelines of service } \\
\text { delivery as good or better }\end{array}$ & $95 \%$ & $99.3 \%$ & $104.5 \%$ \\
\hline
\end{tabular}

As glean in Table 4, it indicates the MFOs and performance indicators that SDSSU needs to accomplish. As shows, SDSSU marks an institutional target but it accomplished more than to its target. Thus, the accomplishment rate of SDSSU in terms of performance in extension is more than $100 \%$. It implies that extension services of SDSSU conforms more than to the expectation and satisfaction of clienteles.

This finding conforms to the statement of Mane and Patil (2015), Neyestani (2016), and Lushi, et.al. (2016) that firms can achieve internal improvements or that standard can assist the firms to maintain or increase their market share by satisfying the customers. Hence, 
customer satisfaction and client satisfaction are the most important aspect of maintaining QMS for construction projects.

Extension services is one of the major functions of SDSSU which is mandated also CHED throughout HEIs of the Philippines. Hence, partnership with stakeholders plays a significant role in bringing the name of SDSSU in international level. This fact conforms to the statement of Lupdag-Padama, et al., (2010) and Rosaroso, et al. (2015) that stakeholders share common conceptions of internationalization in higher education institutions. Hence, it is impossible without partners or linkages that bring us to the third mechanism. Compatible Partnerships bridge local HEIs to the globalized world that may be determined by the global need or gap that the institution intends to fill globally

\section{CONCLUSION}

The profile of the university has potential conformities of high performance, from instruction to extension functions that are essentials for global marketing and competitiveness. Hence, it needs a number of employees, specifically in terms of faculty, as it is seen that the population of students is expecting to be increased due to the free tuition, and availability of grants and scholarship programs. It shows also high performance in terms of program accredited, board programs, and extension services. As to faculty, few meet the educational qualifications but it is evident that majority of them are aiming a highest educational qualifications. Lastly, majority of their level of trainings, conferences, and seminars they attended are in local level.

\section{REFERENCES}

[1] Altbach, Philip G., and Knight, Jane (2011).The Internationalization of Higher Education: Motivations and Realities. Journal of Studies in International Education 2007 11: 290 DOI: $10.1177 / 1028315307303542$

[2] Compe, Alan S. (2018). The readiness of SDSSU for CHED Typology. A Dissertation Presented to the Faculty of the Graduate Studies, Surigaodel Sur State University. Unpublished

[3] Dotong , C.I. \& Laguador, J.M. (2015).Philippine Quality Assurance Mechanisms in Higher Education towards Internationalization. Retrieved from http://research.lpubatangas.edu.ph/wpcontent/upload S/2015/12/SSSHPhilippine-Quality-Assurance-

Mecha on March 9, 2018

[4] Dill, D. and F. Van Vught (eds) (2010), National Innovation and the Academic Research Enterprise;
Public Policy in Global Perspective, the Johns Hopkins University Press, Baltimore.

[5] Egron-Polak, E., \& Hudson, R. (2014).Internationalisation of higher education: Growing expectation, fundamental values. IAU 4th global survey. International Association of Universities.

[6] Engetou, M. (2017).Impact of insufficient personnel on organizational performance. Central University of Applied Sciences. Thesis

[7] Fisher, G. \& Scott, I. (2011).The role of higher education in closing the gaps in South Africa. Technology Analysis and Strategic Management.15 (4):468-489

[8] Flores, R.L.,et.al. (2012). Self-Developed Quality of Working Life Measures, Acta Universitaria; feb/mar2012, Vol. 22 Issue 2, p.24

[9] Gacel-Ávila, J. (2012).Comprehensive Internationalisation in Latin America. Higher Education PolicyDecember 2012, Volume 25, Issue 4, pp 493-510. Retrieved from https://link.springer.com/article/10.1057/hep.2012.9 on March 3, 2018

[10] Green, M.F. (2012). Measuring and Assessing Internationalization

[11] Green, M.F. (2013). NAFSA: Association of International Educators: Improving and Assessing Global Learning.

[12] Hénard, F., Diamond, L., \&Roseveare, D. (2012).Approaches to Internationalisation

and Their Implications for Strategic Management and Institutional Practice.OECD's Higher Education Programme (IMHE). Retrieved from

www.oecd.org/.../Approaches \%20to\%20internationa lisation \%20-\%20final $\% 20 \% 20 \mathrm{w}$ On February 19, 2018

[13] ISO 9001:2015, Quality Management System Requirements

[14] Llopsis, Glenn (2014). Leadership Is About Enabling The Full Potential In Others. Retrieved from https://www.forbes.com/sites/glennllopis/2014/07/2 9/leadership-is-about-enabling-the-ful-l potential-inothers/\#2f8b3c066698

[15] Lupdag-Padama, EA , et.al. (2010). Towards the Development of a Conceptual Framework for Internationalizing Higher Education Institutions (HEIs) in the Philippines. Retrieved from https://ejournals.ph/article.php?id=334 February 11,2018 
[16] Lushi, I., Mane, A., Kapaj, I., \& Keco, R. (2016). "A Literature Review on ISO 9001 Standard," European Journal of Business, Economics and Accountancy, 4(2), pp.81-85.

[17] Mane, P. And Patil J. (2015). Quality Management System at Construction Project: A Questionnaire Survey. Journal of Engineering Research and Applications, 5(3), (Part -3), pp.126-130.

[18] Neyestani, B. (2016). "Effectiveness of Quality Management System (QMS) on Construction Projects".http.doi.org/10.5281/zenodo.290272

[19] OECD (2012).assessment of higher education learning outcomes - OECD.org. Retrieved from http://www.oecd.org/education/skills -beyondschool/AHELOFSReportVolu me 1.pdf

[20] Republic Act (RA) No. 9998. An Act Converting the Surigao del Sur Polytechnic State College (SSPSC) in the Province of Surigao del Sur into a State University to be known as the Surigao del Sur State University.

[21] Republic Act (RA) No. 10931. An Act Promoting Universal Access to Quality Tertiary Education by Providing for Free Tuition and Other School Fees in State Universities and Colleges, Local Universities and Colleges and State-Run TechnicalVocational Institutions, Establishing the Tertiary Education Subsidy and Student Loan Program, Strengthening the Unified Student Financial ssistance System for Tertiary Education, and Appropriating Fund Thereof.

[22] Rosaroso, R. C., Dakay, I., \& Sarmiento, R. (2015). Selected Philippine Higher Education Institutions"e Perspectives on Internationalization of Education: Initiatives and Guidelines. Retrieved http://apjeas.apjmr.com/wpcontent/uploads/2015/10/APJEAS-2015 2.4.1.06.pdf on March 8, 2018

[23] Rosaroso,RC, Yap, CY, \&Gador, S (2015) . Current Initiatives on Internationalization of Education in Selected Higher Education Institutions in the Philippines. Asia Pacific Journal of Education, Arts and Sciences, Vol. 2 No. 4, October 2015(Part II). Retrieved from http://apjeas.apjimr.com/wpcontent/uploads/2015/10/ APJEAS20152.4.1.04.pdf on February 11, 2018

[24] UniRank (2019).

Top Universities in the Philippines 2019 Philippine University Ranking https://www.4icu.org/ph/

[25] Un.org (no date).

Education - United Nations Sustainable
Development https://www.un.org/sustainabledevelopment/educati on/

[26] Xuan, Q. (2015). THE INFLUENCE OF ORGANIZATIONAL CULTURE ON INTERNATIONALIZATION OF MAHIDOL UNIVERSITY. Retrieved from https://grdspublishing.org/index.php/people/article/v iew/17 on February 10, 2018 